\title{
The Political Economy of Development Assistance: Lessons from South Korea for Sub-Saharan Africa
}

\author{
KELECHI A. KALU ${ }^{* *}$ AND JIYOUNG KIM ${ }^{* * *}$
}

This paper examines the political economy of development assistance in sub-Saharan African countries and South Korea focusing on the importance of good governance and domestic politics in a successful management and utilization of development aid. South Korea, along with Malaysia, has been widely recognized as one of the successful cases where foreign aid actually led to a significant level of economic development. From one of the major recipient nations and the poorest countries, South Korea, in about 40 years, has emerged as a donor nation with the $12^{\text {th }}$ largest economy in the world. Comparatively, despite international efforts to help Africans out of their economic and political malaise, there has been a lack of visible progress in sub-Saharan African nations as far as changing the lives of the people. In the paper, we argue that weak institutional and political structures dominated by autocrats and democrats that practice illiberal politics are the main cause of poor development policies in sub-Saharan Africa. It is weak institutional structures that continue to undermine the efficient use of foreign aid in the interest of the people. In this context, we examine political factors that contributed to a successful management of development aid in South Korea, and extract some lessons and policy suggestions from the South Korean case for sub-Saharan African countries.

Keywords: Official Development Assistance, Good Governance, Leadership, Institutional Structures, Developmental State, Efficient Bureaucracy, Foreign Aid

- This paper was prepared for "2008 International Conference: Emerging Donors and New Approaches to Development Cooperation" in Seoul, Korea on December 5. 2008. Kelechi A. Kalu is a Professor of African American and African Studies at The Ohio State University, Columbus, Ohio, USA. Jiyoung Kim is Ewha-KOICA Professor at the Graduate School of International Studies, Ewha Womans University, Scoul, Korea. The authors thank Global Cooperation Center at Ewha Graduate School of International Studies for research fundand helpful comments from the panel and audience of 2008 International Conference; as well as Cynthia Cook for helpful comments on the paper.

- Professor of African-American \& African Studies Director, Center for African Studies BRE: Journal of Asian and African Studies The Ohio State University 386D University Hall 230 North Oval Mall Columbus, OH 43210; Tel: +1-614-292-0758; Fax: 614-292-2293

-. Ewha-KOICA Professor Graduate School of International Studies Ewha Womans University; Tel: +82-2-3277-6796; E-mail: jiyoung.kim@ewha.ac.kr 


\section{INTRODUCTION}

$T$ his paper examines the political economy of development assistance in sub-Saharan Africa and South Korea focusing on the importance of good governance and domestic politics in the successful management and utilization of development aid. South Korea, along with Malaysia, has been widely recognized as one of the successful cases where foreign aid actually led to a significant level of economic development. South Korea, one of the poorest countries and a major recipient nation, has emerged as a donor nation with the $12^{\text {th }}$ largest economy in the world in less than 40 years. Comparatively, despite international efforts to help Africans out of their economic and political malaise, there has been a lack of visible progress in sub-Saharan Africa as far as changing the lives of the people. Indeed, since political independence in the 1960s, official development assistance for many African states has increased. However, there is no visible improvement in either development projects or poverty eradication. Instead, people in many sub-Saharan African states live on less than $\$ 2$ per day. In this paper, we argue that weak institutional and political structures dominated by autocrats and democrats that practice illiberal politics are the main cause of poor development policies in sub-Saharan Africa. It is weak institutional structures largely characterized by poor governance that continue to undermine the efficient use of foreign aid in the interest of the people. By good governance, we are interested in the extent to which governments promote and ensure participatory democracy, human rights, transparency in public decisions, integrity and stewardship of public officials, and the extent to which civil society organizations are free to mediate between the government and the various constituencies that they represent. The goal of this paper does not lie in comparing South Korea with sub-Saharan Africa based on common criteria and variables. Rather, we simply examine political factors that contributed to a successful management of development aid in South Korea, and extract some lessons and policy suggestions from the South Korean case for sub-Saharan African countries.

\section{DISCUSSIONS ON DEVELOPMENT ASSISTANCE AND GOOD GOVERNANCE}

In recent years, many have questioned the effectiveness of foreign aid. For instance, William Easterly (2006) criticized the existing approach to foreign aid, 'Planners' approach, as "misdirected" and "ineffective," and suggested that it largely failed. As an alternative, Easterly proposed a 'Searchers' approach in which recipients' views are well considered and incorporated into the whole process of foreign assistance. Contrary to Easterly, Jeffrey D. Sachs (2005) argues 
that foreign assistance is effective in bringing "the end of poverty" in many developing countries. According to Sachs, many developing nations are poor because they fall into the 'poverty trap,' and foreign assistance is the solution for escape. Suggesting that the world needs to increase the amount of foreign assistance to developing nations, Sachs (2005: 246) writes "foreign help, in the form of official development assistance (ODA), helps to jump-start the process of capital accumulation, economic growth, and rising household incomes."

In practice, it is difficult to assess and measure the effectiveness of development assistance. Most of all, there are data problems. Not only are the data on the effects of development assistance lacking, unclear, and subjective, but only a small fraction of aid projects have been formally evaluated. In addition, there is a problem of data bias as most of the relevant non-government organizations would insist that their foreign assistance activities have all been effective. However, one thing is clear: in most cases, development assistance has failed to bring about a long-term economic growth or noticeable reduction in the poverty rate, especially in African countries. In addition, a lack of good governance in the recipient nations has been pointed out as one of the most important obstacles to economic development and the effective use of foreign aid. More specifically, absence of strong and sound political leadership, corruption, inefficient administrative system, and social and political instability remain the main causes of poverty and underdevelopment in many developing nations, especially in subSaharan Africa.

In this study, we emphasize the importance of good governance in bringing about economic growth and the effective utilization of development assistance by examining the political economy of sub-Saharan African countries and South Korea. In particular, focusing on the role of the state in managing and utilizing development assistance in sub-Saharan Africa and South Korea, we show that a lack of good governance, inefficient and corrupt states, and ineffective use of foreign assistance are the main causes of underdevelopment in sub-Saharan Africa. In South Korea, on the other hand, the developmental state played a leading and effective role in utilizing and managing development assistance.

\section{POLITICAL OBSTACLES TO THE EFFICIENT USE OF DEVELOPMENT ASSISTANCE IN SUB-SAHARAN AFRICA}

Those familiar with problems of poor governance in sub-Saharan African states will recognize the trajectories the discourses on African politics have taken since the 1960s. Mostly following political independence in the 1960s, analysts were focused on types of governments without considering the role of individuals in various structures and institutions of government. In the 1980s, the concern was with individuals and their rational capacity to make public policy decisions 
to the extent that they were not constrained by either government or stat institutions. With the end of the Cold War in the early 1990s, scholarship or Africa has reverted back to states, with keener emphasis on state structures: coalitions and civil society organizations, and their roles in good governance. The problem here is that much of the discourse that emphasized the forces behind democratization have largely failed to analyze the nature of the state in Africa, which failed to show progress in economic or institutional development since the 1960s. We argue that without adequate attention to the nature of the state-its emergence and resilience-analysis of development or its failure in sub-Saharan Africa is unimaginative. Consequently, the emergence of the African state system from the Berlin Conference of 1884-1885 is a problem of development in Africa. More specifically, European interference in the internal processes of state formation in Africa continues to undermine the capacity of the African states. This is especially true south of the Sahara, undermining the capacity to serve as vectors of development either through the use of indigenous resources or effective management of overseas development assistance for economic growth. Lumping ethno-nationalities with cultural and socio-economic differences within the same political platform based on suppressed cultural/political leadership transition strategies planted the seed of autocracy, corruption, and the emergence of poor managers of state resources. While historically, the formation of state systems in Europe helped to enhance the power and prestige of dynasties by making war and extracting economic resources, European state formation in Africa strategically enhanced the development of European states and the implantation of internally corrupt and mostly incompetent leaders in independent Africa.

Similarly, as centers of despotic rule, the European state system in the $18^{\text {th }}$ century cared very little about the concerns, welfare, or freedoms of the people. This nonchalant view of the people remains one of the legacies of European leadership in sub-Saharan Africa. European monarchs ruled with the help of a cadre of assistants acting within the framework of an effectively organized bureaucracy. African governments, however, were composed of a directionless, non-strategic, emasculated bureaucracy, and non-visionary leadership surrounded by sycophants (Gordon 1999, 1-11). Consequently, in Europe, the social organization known as the state became the basis for exercising political influence and broadcasting power (Herbst 2000, 21-22) from the seat of government to the entire territory claimed for a particular state. For sub-Saharan Africa, however, the state and its apparatus is mostly located in the capital cities and serves as a platform for contested wealth accumulation rather than nation-building. It is thus the weak nature of state institutions and lack of indigenously focused leaders with competence in economic and political management that continue to undermine the capacity of African governments to source and use official development assistance to ensure economic growth. 
Briefly mapping out the nature of the weakness of the African state in comparison to non-African state formation will be helpful for understanding the nature of the state as an obstacle for effective use of official development assistance.

According to Kalu (2001), writing about the concept of state often evokes a dilemma: one either accepts a broad and therefore relatively insignificant definition of the state or agrees that the state is "... not a universal concept but rather the product of a specific historical crisis $\cdots " 1$ that gives rise to the social formation and political organization of a given geopolitical experience. The modern state is rooted in a specific Western experience. It came out of the 1648 Treaty of Westphalia that ended the thirty years war between Catholics and Protestants. The literature on the nature and functions of the state spans all theoretical and analytical positions. ${ }^{2}$ From a Weberian perspective, a state exists if it can exercise a monopoly on the use of force in a given territory. Based on Weber's definition, African states do exist as they exert considerable force, domestically-but consistent with Herbst argument, the extent to which they exercise the monopoly of use of force in their territory is questionable. However, given the volume of official development assistance, internationally-sanctioned debt over hang, state-to-state relationships, and consistent with the language and intent of the 1648 Treaty of Westphalia, African states exist as "legal person[s]" characterized by a given geographical territory, population, government and political independence that confers the status of sovereignty on these states. But from the Marxist's perspective, although the state will eventually "wither away," it reflects the economic interests of the ruling class; which according to Claude Ake is a more apropos description of the contemporary African states. Statists like Stephen Krasner see the state as a composite of (1) politics more as a problem of rule and control, (2) state as an actor in its own right, (3) formal and informal institutional constraints on individual behavior, within a platform of (4) a sense of history with its disjuncture and stress on the socio-political formation of the territory and people. Also, in contrast to a Marxist view of the state, Krasner (1978: 10) conceives of the state as "a set of roles and institutions having peculiar drives, compulsions, and aims of their own that are separate from the interests of any particular societal group." From that perspective, the state is an abstraction with no particular intent or design to reward any individual or group in society-which is a proper characterization for a social organization of humans where the superstructure is transparently neutral in protecting and enabling the economic productive energy of the citizens. Thus, the state's generally agreed-on central function of ensuring the national security of its territory, maintaining law and order, and welfare ${ }^{3}$ should be executed without regard to class, coalition and individual interests. At the very least, it should pretend its neutrality is strategically positioned to favor economic blocs that help industrialize the state as was the case in many pre-industrial states; i.e. Japan, United Kingdom, United States and South Korea. 
The existence of the state is dependent on an efficient bureaucracy with the capacity to collect revenue and utilize its natural and human resources. That is, the state is apolitical-a realist notion that is fraught with problems for explaining a state's vector role in economic development. If we accept the abstract nature of states from the realist perspectives, we must conclude that the state is nothing but an umpire in the game of politics where the players are real human beings with, sometimes, bitterly contested interests. It also follows that such a state is autonomous and unaffected by the different political machinations within it. Given that such a state is likely to be ineffective in its security or economic functions as evident in many sub-Saharan African states, the likelihood exists that other states, more economically and politically efficient, will dominate and out-maneuver it externally and internally-therefore compromising the state's capacity for ensuring viable economic development policies and implementations. And because states have real, significant and consequential roles to play in domestic and foreign economic policies, failure results in incessant incapacity for transformative change and perpetual dependence on official development assistance. Where good governance is characterized by popular sovereignty (the idea that government policies reflect the general wishes of the governed), citizens' choices impact government decisions. Given that the interest of the state is maintained by the government, we argue that politically and economically competent states are sensitive to the effect of external policies, especially when such official development assistance and structural adjustment policies have the capacity to undermine internal economic growth as the case of sub-Saharan Africa demonstrates. The empirical question here is: why have the African states failed to effectively engage in domestic and foreign economic policies that enable development similar to those experienced in South Korea?

Writing about the emergence of states, Charles Tilly argues that European states emerged out of violent conflicts between self-seeking, violent, and coercive forces rather than the sanitized notion of a social contract between the citizens. $\mathrm{He}$ argues that "coercive exploitation $\cdots$ banditry, piracy, gangland rivalry, policing, and war making" (Tilly 1985) are central to understanding the rise of European social formation and system of government within the framework of the state. In contrast to Africa, the emergence of the state system in Europe and Asia is clearly different. Since in Africa the states were externally created and imposed, colonial and postcolonial states did not need war making to survive; disproportionate effort was on extraction, not on state or war making. They essentially became gatekeeper states extracting revenue from import licenses and fees, loans and foreign aid that did not need engagement with the people and, therefore, no need to offer concessions as a platform for nation-building. Given that postcolonial states such as those in Africa did not establish their militaries from internal arrangements of powers, and/or struggle between the rulers and ruled, it was not difficult for the postcolonial African militaries to metamorphose 
from their security functions to contest for political power through force. Consequently, the imposed army receiving its military training, equipment, and support from outside the continent became an unconstrained organization of force over and above other institutions within the state. To the extent that the state boundaries remain sacrosanct, the managers of the military organizations exercised extraordinary power within the state-further weakening the capacity of state institutions to carry out governmental functions. Subsequently the state itself becomes a prize to be fought over as generator of extractive resources without negotiating with the masses. The direct result of the foregoing is that in Africa the state became a 'true' gatekeeper entity negotiating between foreign governments and agencies without input from the people either as political interest groups or economic entrepreneurs. Since the leaders had private gains as their main interest in government, official development assistance largely ended up in private hands rather than enabling effective economic development policies as the case of South Korea shows.

Furthermore, at the center of state-making in Europe were the feudal aristocracies whose apperites for wealth accumulation led them to seize as much of the land and real estate within Europe. As Tilly and Herbst argue, securing these territories required the building of standing armies with the capacity to enforce extractive rules of taxation from the people as a precondition for defending them against external threats. The landlords on behalf of the Aristocrats were able to forcefully compel the citizens to pay taxes as part of their responsibilities to the kings and in return their protection was assured against external enemies and potentially organized enemies within state boundaries. As extraction increased the capacity of the kings to make war, they were able through the establishment of citizens' armies to perpetuate their control and authority over the citizens within their territories, and therefore laid solid foundations for the broadcasting of power and authority over their states. Thus, through increased extraction, external enemies are eliminated through war, territorial boundaries expanded to accommodate rising populations, and internal threats to the authority of the state is silenced. Over time, resources were managed such that the public interest was preserved and politics was liberalized.

According to Jeffrey Herbst, ${ }^{4}$ European states were able to accomplish their tasks because of the unique context of their social formation-high population density and scarcity of land, which forced leaders to go to war in order to acquire more territories to accommodate their growing population. The wars helped create nationalism and the state. But it was the capacity of the state to build effective infrastructures-roads, defense and communication networks, that made it possible for the emergence of consolidated, powerful European states. But Herbst argues that the weak nature of states in Africa is not due to size but to the vast geography and low population density. Consequently, to the extent that postcolonial African leaders did not redesign the colonial boundaries they 
remain trapped within the institutional structures of the colonial power system that located the authority and power of governments away from the people. Such concentration of power within the capital cities makes nonsense of any notion of territorial integrity of the state. In this respect, most of the government officials are neither concerned about the welfare of the rural inhabitants nor engaged in implementing policies that aim to integrate or link the rural areas to the capital cities. Consequently, without insisting on effective government reform of institutions, the building of nationalism and an effective bureaucracy, continuing foreign aid will yield the result that scholars continue to bemoan-the waste of ODA to the tune of almost $\$ 500$ billion-and no poverty alleviation or sustainable economic growth.

According to Hannah Arendt, "Power corresponds to the human ability not just to act but to act in concert. Power is never the property of an individual; it belongs to a group and remains in existence only so long as the group keeps together." 5 Thus, the "organized few can invariably dominate the unorganized many" (Gordon 1999, 11), especially in a social relationship where the organized few have the economic and coercive resources to dominate and control the relationship with and within the unorganized many as evident in the colonial encounter between the West and Africa. As Claude Ake notes, the colonial state was effectively organized to act unilaterally on matters of public policy like land redistribution and in the appointment of key actors in economic production processes without regard to existing mode of social relations. The colonial state "attended to the supply of labor, sometimes resorting to forced labor; it churned out administrative instruments and legislated taxes to induce the breakup of traditional social relations of production, the atomization of society, and the process of proletarianization" (Ake 1996, 1-3). Educationally, the colonial state ensured that Africans received only minimal training sufficient for performing assigned tasks and to "remain steadfast in the performance of their often tedious and disagreeable tasks" (Ibid.). Infrastructurally, the colonial state "built roads, railways, and ports to facilitate the collection and export of commodities as well as the import of manufactured goods" (Ibid.), without regard to sector and urban/rural linkages or the extent to which these infrastructures could be used to enhance lives in Africa. In addition, the colonial states "sold commodities through commodity boards," and "controlled every aspect of the colonial economy tightly to maintain its power and domination and to realize the economic objectives of colonization" (Ibid.). As the objectives of the colonial state in Africa were mainly resources exploitation, very little attention was paid to the political and economic welfare of the people.

Institutionally, there were no mediating structures between the state and the people that could be relied on to adjudicate disagreements fairly and justly. Thus, at independence, a major legacy of the colonial state was the coercive institutions of violence, which the postcolonial leaders quickly co-opted into 
their battle against one another for the power vacuum created by decolonization. Thus, the postcolonial state in sub-Saharan Africa is not very different from the colonial state. "It continues to be totalistic in scope," remains an "apparatus of violence," with a very "narrow social base," and relies on institutions of coercion rather than authority in making and implementing public policy. In many instances, it is as if the colonialists have not left. This has led Ake to argue that the struggle for political independence "more often than not $\cdots$ was a matter of the colonizers' accepting the inevitable and orchestrating a handover of government to their chosen African successors, successors who could be trusted to share their values and be attentive to their interests" (Ake 1996, 4-5). Thus, "while agitating to overthrow the colonial regime," the nationalists and their various coalitions were also trying to block one another from appropriating the power of the state; and with time, "their attention turned from the colonial regime to one another; and eventually the competition among these groups came to dominate political life, while the colonial power, now resigned to the demise of colonialism, became a referee rather than the opponent" (Ibid.).

Comparatively, the World Bank's governance indicators show a miserable result for African states. As Table $1^{6}$ shows, except for voice and accountability, subSaharan African countries rank the least in terms of governance relative to South Asia and Middle East/North Africa regions. Indeed, compared to South Korea, sub-Saharan African states are empirically low governance regions that are consistent with its low economic performance as the HDI data will show later. The low governance scores show the low capacity that African states and government have in building essential infrastructures such as road networks, rail lines, communications grid, energy supplies and other basic services the citizens rely on to unleash their entrepreneurial capacities in other regions. Furthermore, we argue that the low capacity that the data indicate makes it difficult for sub-Saharan African states to attract diversified foreign direct investments into the various countries. Thus, low capacity that is rooted to the nature of the state equally makes it difficult for such a state to effectively use official development assistance for purposes of economic development. Rather, without reforming such a state, the continued outcome will remain low capacity, ineffective public policies and therefore, corruption that undermine development.

Consequently, without rethinking and reforming the state in Africa, all efforts at economic development-internally or through official development assistance-will continue to fail because the indigenous social formations across the continent are yet to reconcile themselves with the project of nation-building. Most African governments preside over weak political and economic structures that encourage predatory economic behavior, corruption and incompetence. As a result, public officials fail to use the state as a platform for enabling economic development, efficient use of foreign aid and in all, fail to politically ensure the security of their people. It is indeed the ordinary Africans who do not see the benefits 
of political independence, economic development or official development assistance; it is as if the colonialist had never left.

TABle 1. Governance Indicators/SCORES 2007

\begin{tabular}{c|c|c|c|c}
\hline $\begin{array}{c}\text { Governance Score for 2007 } \\
(-2.5 \text { to }+2.5)\end{array}$ & South Korea & $\begin{array}{c}\text { Sub-Saharan } \\
\text { Africa }\end{array}$ & South Asia & $\begin{array}{c}\text { Middle East and } \\
\text { North Africa }\end{array}$ \\
\hline Voice and Accountability & +0.66 & -0.55 & -0.69 & -0.88 \\
\hline Political Stability & +0.45 & -0.53 & -1.32 & -0.51 \\
\hline Government Effectiveness & +1.26 & -0.77 & -0.50 & -0.21 \\
\hline Regulatory Quality & +0.88 & -0.74 & -0.61 & -0.17 \\
\hline Rule of Law & +0.82 & -0.75 & -0.46 & -0.04 \\
\hline Control of Corruption & +0.36 & -0.64 & -0.56 & -0.07 \\
\hline
\end{tabular}

SOURCE: Compiled by the authors from World Bank Governance Indicators at http://info.worldbank.org/governance/wgi/index.asp 2009.

\section{THE ROLE OF THE GOVERNMENT IN THE USE OF DEVELOPMENT ASSISTANCE IN SOUTH KOREA}

South Korea's developmental state was the main contributor to an effective management and usage of foreign assistance. In Embedded Autonomy, Peter Evans (1995) compared and contrasted the predatory state and the developmental state using Zaire (Democratic Republic of Congo) for the former and Japan (archetype of the developmental state), Korea, and Taiwan for the latter. According to Evans, a predatory state "... preys on its citizenry, terrorizing them, despoiling their common patrimony, and providing little in the way of services in return" (Evans 1995, 45). This concept of predatory state is very similar to the notion of gatekeeper states in the sense that both highlight the ineffective and exploitative role of the state: the former focuses more on the role of the state within a society while the latter concentrates on the state's position in the international and domestic spheres. It is this nature of gatekeeper states and their weak economic policy institutions which do not engage the citizens in sub-Saharan African countries to bring about economic development and stability. The South Korean case, on the other hand, exemplifies the role of the state as necessary manager of the various factors and institutions for sufficient impact in achieving economic growth. In particular, in this section, we examine the role of the South Korean government in managing and making the best use of foreign assistance focusing from the period of the 1950s-1980s when South Korea was still a major official development assistance (ODA) recipient nation. Through 
a close analysis and examination of the relationship between the role of the government and foreign assistance and the political economy of its mechanism, we argue that good governance was the precondition for an effective use of foreign assistance in South Korea.

\section{Contextual factors}

From one of the poorest, major recipient nations in the 1950s, South Korea, by the late 1980 s became the $12^{\text {th }}$ largest economy in the world. Today, South Korea is pursuing the effective donor country role by engaging herself actively in foreign assistance projects. Behind this miraculous economic growth was the generous development assistance from the international community. After its independence from Japan in 1945, South Korea received development assistance from many countries including the U.S. The U.S. was the major donor country of South Korea, especially after the Korean War (1950-1953). During the period of 1954-1960, South Korea recorded $4.9 \%$ annual growth rate and $11.8 \%$ annual investment rate, and the major source of investment was foreign grant and assistance. ${ }^{7}$ After the late 1950s, foreign grant was replaced by development loan. For the period of 1945-1999, South Korea received around 127 billion U.S. dollars, and in 1995 South Korea was removed from the World Bank's list of recipient nations (KOICA database).

How do we explain South Korea's successful management and use of foreign assistance? We begin with examining some contextual factors. Even though the Korean people suffered enormously as a consequence of the Cold War, the rivalry between the two superpowers that led to the Korean War (1950-1953), and the division of the country, South Korea has been one of the largest beneficiaries of the Cold War via U.S. support and foreign assistance. Recognizing the geopolitical importance of South Korea, the U.S. provided an enormous amount of foreign aid to South Korea. Throughout the period of 1945-1995, the U.S. was the largest donor country for South Korea, followed by Japan. The amount of bilateral aid that the US provided to South Korea during the period reached around 55 billion U.S. dollars in total (KOICA database).

Also, as Table 2 indicates, a major proportion of the aid to South Korea was bilateral. Such structural characteristics of the foreign assistance to South Korea contributed to an effective use of the aid for the following reasons. First, South Korea did not have to deal with a number of different donors since most of its aid came from the U.S. Second, the U.S. government was deeply involved in the management of the aid. Thus, as a consequence the South Korean government did not have to deal with various donors, which afforded it the opportunity to consistently plan, monitor, manage and evaluate policies in collaboration with competent economic policy experts from the U.S. We would argue that such a flexible and cooperative effort between the U.S. and South Korea 
that resulted in an efficient use of the foreign aid was absent, and remains so in the case of sub-Saharan Africa where the gatekeeper states in collaboration with the aid donors (or because of the multiplicity of donor sources) are often not concerned with whether the aid reaches the intended population. For instance, in order to simplify the process and maximize the efficacy of foreign assistance, the Rhee government adopted the American fiscal year system which begins in July and ends in June. ${ }^{8}$ Later the Park government used the five-year development plan as a strategy to shift the economy from labor-intensive to technology-intensive industry that targeted chemical and heavy manufacturing concerns. Many African states adopted the five-year development plans that were often abandoned because as Claude Ake argues, development was never part of the policy agenda and there was no consistent strategy for national development.

TABle 2. Oda to SOUTh Korea

(in million US dollars)

\begin{tabular}{lccccc}
\hline & $1945-$ & $1961-$ & $1976-$ & $1991-$ & TOTAL \\
& 1960 & 1975 & 1990 & 1999 & \\
\hline \multirow{2}{*}{ GRANT (\%) } & $3,045.6$ & $1,999.0$ & 750.4 & $1,202.5$ & $6,997.5$ \\
& $(98.3)$ & $(50.7)$ & $(21.4)$ & $(54.0)$ & $(54.8)$ \\
LOAN (\%) & 52.3 & $1,942.4$ & $2,760.4$ & $1,023.7$ & $5,778.8$ \\
& $(1.7)$ & $(49.3)$ & $(78.6)$ & $(48.0)$ & $(45.2)$ \\
BILATERAL (\%) & $2,518.4$ & $3,312.2$ & 2.200 .0 & $2,200.0$ & $11,807.9$ \\
& $(81.3)$ & $(94.3)$ & $(98.8)$ & $(98.8)$ & $(92.4)$ \\
MULTILATERAL (\%) & 579.5 & 198.6 & 26.2 & 26.2 & 968.4 \\
TOTAL & $(18.7)$ & $(5.7)$ & $(0.2)$ & $(0.2)$ & $(7.6)$ \\
\hline
\end{tabular}

SOURCE: KOICA database.

Third, the Vietnam War was another important contextual factor that contributed to South Korea's foreign exchange income in the late 1960s. Pressured by the U.S., the South Korean government sent approximately 310,000 troops to Vietnam between 1964 and 1975. In return the U.S. government provided the Korean government with various economic benefits: South Korean construction companies were allowed to participate in the bidding for construction projects in Vietnam, and the U.S. purchased Korean products for American soldiers in Vietnam. As a result, Vietnam was the third largest export market for Korea in the late 1960s after the U.S. and Japan. In addition, as South Korea dispatched troops to Vietnam, the U.S. government increased its military assistance to South Korea eliminating the latter from the burden of national defense and enabling South Korea to focus on economic development. Clearly, the geostrategic location of South Korea to the U.S. during the Cold War regarding national security interests was pure luck of geography. However, there are also the deci- 
sion-makers in South Korea who saw the opportunity to advance their economic and political interests, and chose to do so, in contrast to consistent economic and political opportunism on the part of decision makers in sub-Saharan Africa.

In addition, as opposed to many sub-Saharan African countries, South Korea enjoyed continuous and sustained inflows of foreign assistance though there were some fluctuations in the amount from time to time. Such a continuance of foreign aid allowed the government to develop specific plans to utilize the funds. As previously mentioned, South Korea's geopolitical importance was a critical reason why the U.S. and other countries continued to provide funds to South Korea. More importantly, the successful management and utilization of foreign aid itself further convinced donor countries to provide continuous support to South Korea. With this understanding of contextual factors, we will examine che domestic political economy of development assistance in South Korea focusing on the role of the state.

\section{Development assistance to south korea during the rbee era}

The three-year Korean War (1950-1953) bankrupted the South Korean economy. Throughout the 1950s South Korea heavily depended on foreign assistance, especially the U.S., for its national income. As mentioned earlier, recognizing the geopolitical importance of the Korean peninsula, the U.S. provided a large amount of aid to South Korea. By the mid-1950s, South Korea was the second largest recipient of U.S. aid. The increase in the amount of foreign aid together with the growth of domestic production led to a fast recovery of South Korea's economy after the war. Throughout the 1950s the U.S. and South Korea maintained close communications regarding the use of aid through the Combined Economic Board (the Board), a board that was created right after the armistice in 1953. Through the Board, the U.S. and South Korea distributed and managed the aid. The Board did not only oversee the process but developed specific economic stabilization plans for the South Korean economy. As the Rhee government (1945-1960) was heavily dependent on the U.S. for its aid, the influence of the Board was critical in determining the government's economic plans. During this period of time, South Korea's sovereignty and independence was largely restrained as its economy and military was heavily dependent on the US.

The results of the strategic coordination between the United States and South Korea is shown by the fast recovery of the economy after the war (see Table 3) such that by 1956 Souch Korea achieved pre-war economic level of success. The war had strengthened patriotism and the citizens' commitment to the development of the country. It also prevented serious government corruption since the government was pre-occupied with defending the country from North Korea. Also, the war created the 'strong state, weak society' structure in South Korea since it destroyed the civil society; the government and military became the 
strongest institutions in the country. All of these factors contributed to the emergence of a "developmental state" in South Korea. Until the end of the 1970s, all the financial intuitions in South Korea were government-owned. Through financial institutions, the government of South Korea could directly control the private sector. The government in collaboration with the military steered the country towards economic growth which transformed South Korea from a recipient to a donor.

TABle 3. Major ECONOMic Indicators of SOUth Korea (1953-1960)

\begin{tabular}{cccc}
\hline Year & GNP & $\begin{array}{c}\text { Growth Rate } \\
(\%)\end{array}$ & $\begin{array}{c}\text { Foreign Grant } \\
\text { (in million US dollars) }\end{array}$ \\
\hline 1953 & 41.62 & - & 194.2 \\
1954 & 59.72 & 6 & 153.9 \\
1955 & 101.81 & 6.3 & 236.7 \\
1956 & 131.63 & 1.3 & 326.7 \\
1957 & 171.52 & 7.2 & 382.9 \\
1958 & 182.01 & 6.1 & 321.3 \\
1959 & 196.43 & 4.6 & 222.2 \\
1960 & 218.78 & 1.8 & 245.4 \\
\hline
\end{tabular}

SOURCE: J. Kim (1988: 241).

However, one has to be careful in assessing the role of foreign aid in Korea's economic development during the Rhee Seung Man era. The most important policy objective during this time was rebuilding and strengthening the military power rather than achieving economic progress. Naturally, the Rhee government used most of the foreign aid for national defense while only a limited amount was invested in development. During the period of 1953-60, 40 percent of South Korea's national defense expenses were covered by foreign aid (J. Kim 1988). It was only after the Park Chung Hee era (1962-79) when South Korea actively began its economic transformation, and the main role of foreign assistance was changed from military assistance to development aid.

\section{The Era of developmental state and political economy of foreign assistance}

Since the late 1950s U.S. aid to South Korea has declined due to changes in the U.S. political and economic environment that included a record deficit in its international payments. The U.S. also has been criticized for delaying the economic independence of South Korea. In 1961, the Kennedy administration replaced the Mutual Security Act with the Foreign Assistance Act (FAA). The 
main contents of the FAA provided that: 1) military aid should be separated from the development assistance; 2) the type of assistance be changed from grant to loan and; 3) the U.S. will strengthen the "Buy American policy.' As the South Korean government depended heavily on foreign aid, such a sudden and drastic change in U.S. foreign policy came as a shock to the Korean people. As shown in Table 2, the proportion of grant aid decreased by almost 50 percent between 1945-1960 and 1961-1975. Even though the Vietnam War and normalization of diplomatic relations between South Korea and Japan contributed to South Korea's foreign exchange income, such a drastic change in the U.S. aid policy constituted a crisis for the government. In retrospect, however, such a crisis contributed to South Korea's economic independence as the Park Chung Hee government (1962-1979) was successful in transforming this crisis situation into a new opportunity, the developmental state.

On May 16, 1962, a military general, Park Chung Hee led a coup that overthrew the Jang Myun government. 10 Suppressing democratic movement by force, Park came to power and established an authoritarian, developmental regime. Park borrowed heavily from Japan for South Korea's new economic development model. He ruled the country for almost 40 years until his assassination in 1979. Even though the Park Chung Hee regime (1962-1979) was criticized for its lack of political legitimacy and authoritarian rule, it was under this leadership that South Korea recorded a miraculous level of economic growth. It was the high period of the developmental state.

According to Peter Evans (1995), a developmental state presides over industrial transformation and plays a leading role in making development happen. Main characteristics of South Korea's developmental state include: 1) strong leadership; 2) efficient and talented bureaucracy; 3) pilot agency (e.g. Economic Planning Board); and 4) weak 'civil' society. The question is: how did the Park Chung Hee government successfully transform South Korea into a developmental state? Korea's Confucian culture, long history of bureaucracy, governmental will and strong leadership, and weak civil society have been offered as explanations or factors that contributed to the establishment of the developmental state. Here, by examining closely how Park responded to the decline in U.S. aid, we highlight the importance of strong leadership in the advancement of the developmental state.

As we have noted above, the South Korean government transformed the crisis situation into a new opportunity by working with strong political economic institutions to foster economic growth and improved standard of living. Uncertainty in this case unleashed the regime's creative juices as the sharp drop in U.S. foreign aid led the government to implement a series of policies to reform its fiscal structure. In addition, the Park government actively sought out other sources of foreign income.

Economically, in 1962, the Park government revised and enacted a "Law 
on the Attraction of Foreign Capital" to facilitate the attraction of foreign money. Diplomatically, in 1965, the Park government normalized its diplomatic relationship with Japan to invite a grant and commercial loan from the latter. In addition, the Park government strategically expanded the number of donor countries to include international organizations and European countries (See Figure1). As Figure 1 indicates, since 1966, public loans from Japan, international financial institutions (IFIs) (including World Bank, International Financial Commission, and Asian Development Bank), and European countries such as West Germany, the United Kingdom, and France have increased. In 1966 the World Bank assisted in the development of the International Economic Consultative Organization for Korea (IECOK). Through IECOK, international financial institutions and the South Korean government met regularly to discuss the nation's economic policies and effective use of foreign aid (KOICA 2004).

Figure 1. Public Loan to South Korea from Major Donors, 1966-1992

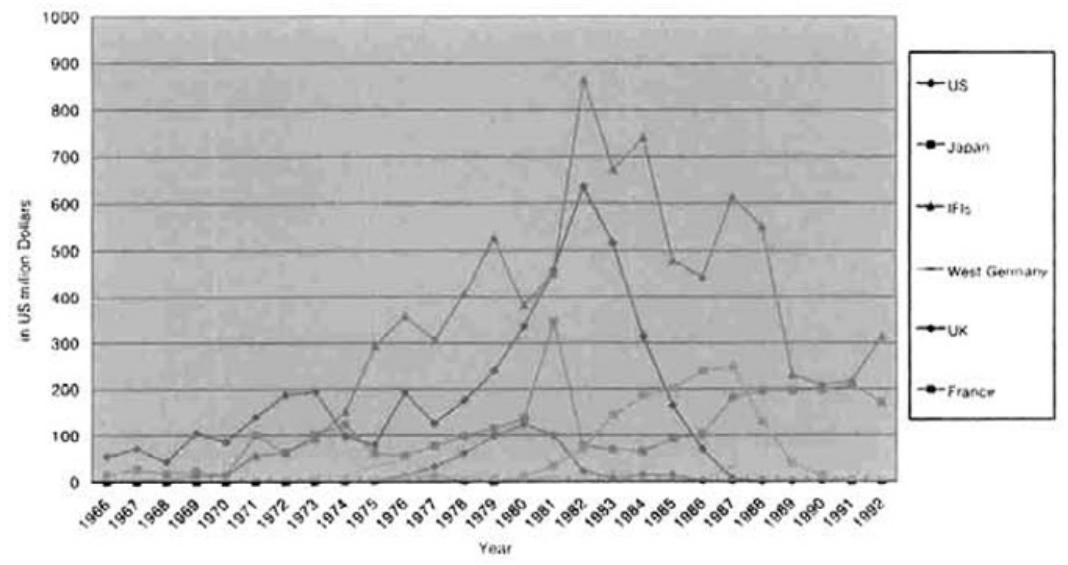

SOURCE: Ministry of Finance; Korea Industrial Bank 1993.

Government leadership, ownership, and active participation in attracting foreign aid contributed to South Korea's economic success during the Park Chung Hee administration. South Korea's economic success was validation for the donors of the effectiveness of their development assistance. Adopting the Japanese model, the Park government focused on the export-led strategy and succeeded in transforming South Korea's industrial structure from labor-intensive to technologically intensive. More specifically, since 1962 the government adopted five-year economic plans to develop coherent and focused national plans for its economy. In particular, in 1972, the Park government began heavy and chemical industrialization and selected target sectors including shipbuilding, steel, electronics, and automobiles. The government provided these selected target industries with subsidies that 
enhanced both their product efficiency and competitiveness. The government set goals and pressured the businesses to achieve these goals through incentives, including financial subsidies. Domestic and international factors such as strong leadership, a national economic plan, talented and autonomous government bureaucrats, and suppressed labor unions as well as the U.S. government's willingness to open their markets to South Korean products all contributed to rapid economic growth of South Korea. ${ }^{11}$

The Park government used foreign assistance to achieve its specific economic goals. Foreign assistance was not managed separately for particular sectors and purposes, but used together with domestic savings to achieve long-term economic goals. Figure 2 shows that from the late 1960s to the early 1970s when the Park government was implementing the 'New Village Movement' to increase agricultural productivity, foreign assistance was mostly invested in the agricultural sector. After the 1970s, the Park government began industrial transformation toward heavy and chemical industry. The development assistance was mainly used in building infrastructure such as highways and bridges, which were essential preconditions for a successful industrial transformation.

Figure 2. USage of Public Grant by Sectors, 1966-1992

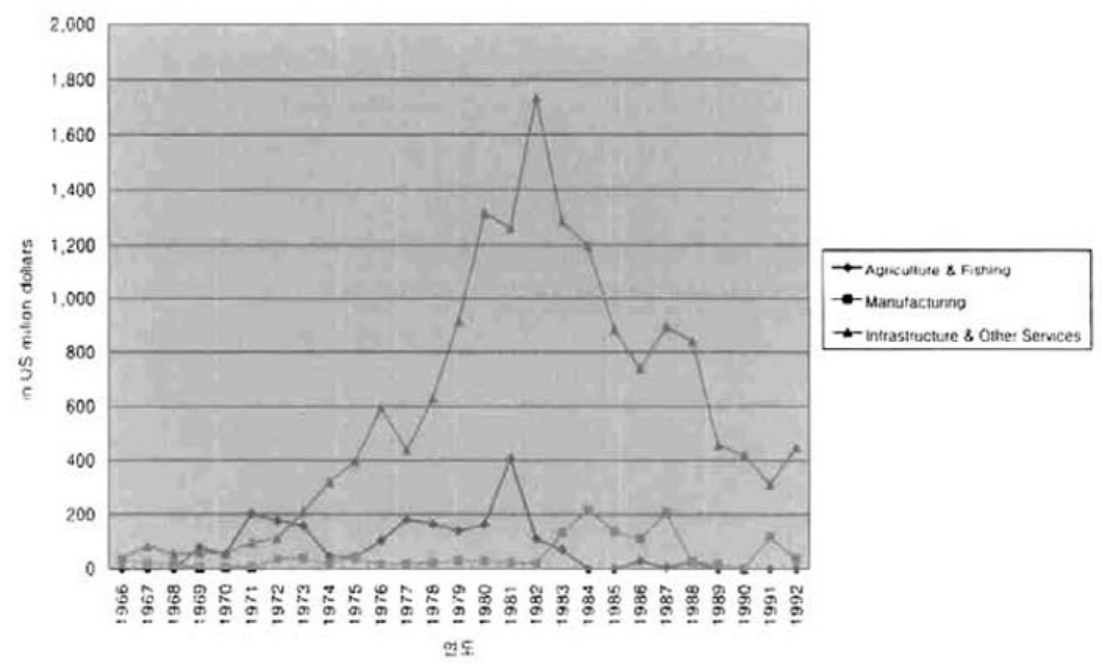

SOURCE: Ministry of Finance; Korea Industrial Bank 1993.

However, the amount of foreign assistance declined with the growth of the South Korean economy for the following reasons. First, with economic development, South Korea did not have to depend on foreign assistance in achieving its economic plans as domestic savings grew markedly. Also, as Figure 3 indicates, over time, the amount of public loans decreased and the loans from the commercial sector, foreign banks, and financial institutions grew, indicating that the South Korean $_{4: 04 A M}$ 
economy moved toward market liberalization and deregulation so international investors were willing to invest in her economy.

Figure 3. Foreign Capital. to SOUTh Korea, 1945-1992

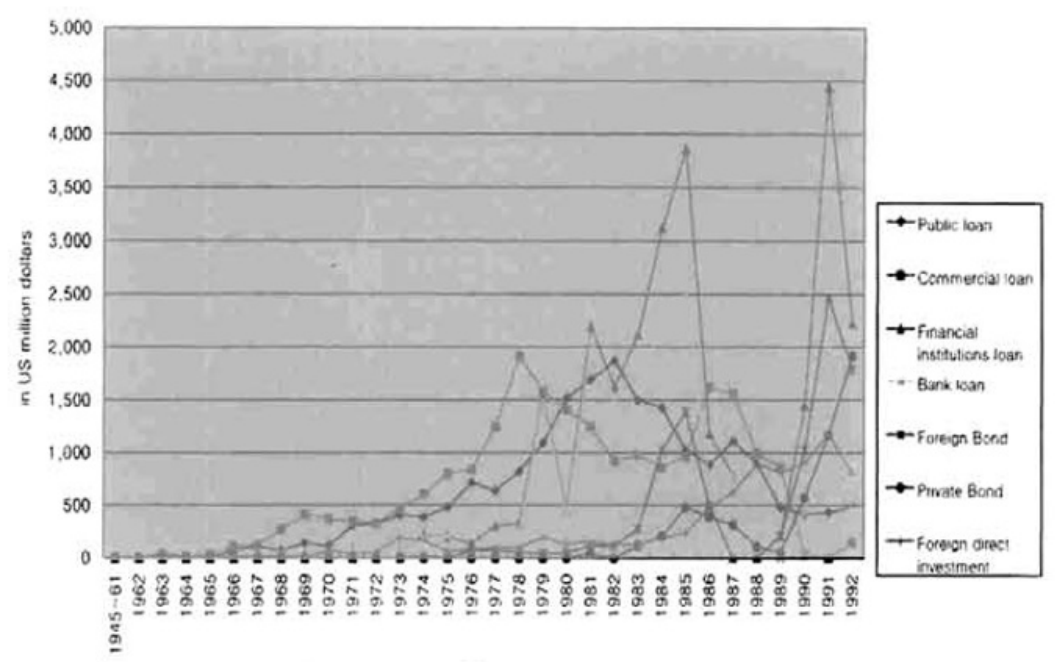

SOURCE: Ministry of Finance; Korea Industrial Bank 1993.

Empirically, we can conclude there was a strong correlation between good governance, foreign assistance, and economic growth for South Korea (see Figure 4). Good governance was a necessary condition for the effective use of foreign aid, which consequently contributed to economic growth. In summary, the South Korean success story is a recipe for attracting domestic and foreign investments to grow an economy; i.e. strong policy institutions and political stability.

Figure 4. Positive Cycle of Good Governance, Foreign Assistance, and ECONOMIC GROWTH IN SOUTH KOREA

Good governance $\longrightarrow$ Effective Use of Foreign Aid $\longrightarrow$ Economic Growth More aid from Donors $\longrightarrow$ Further Economic Growth

\section{CONCLUSION}

According to Sachs (2005), food productivity was the most important determinant for Asian countries in escaping the poverty trap. Sachs also pointed out that because Asian countries had better social conditions such as higher literacy rate, lower infant mortality, and lower total fertility rates, they were therefore less 
likely to fall into a demographic trap (Ibid.). Sachs, however, did not fully explain why Asian countries had higher food productivity and better social conditions than many African nations, overlooking the active role of the government in achieving these important and fundamental goals. For instance, in South Korea, the Park government promoted the "New Village Movement" to improve food productivity and actively campaigned to lower fertility rates.

Empirically, it is plausible to conclude that sub-Saharan African states can have strong institutions without stifling domestic creative energies by targeting the use of foreign aid, domestic savings, and political stability to transform their countries from aid recipients to potential aid donors. The South Korean case has highlighted the importance of an active state role in maximizing the effect of foreign aid and making it a long-term investment for economic growth. This government has provided a blueprint for a national economy by using limited financial resources to achieve specific economic goals. In South Korea, there were no other private channels, besides the government, through which the foreign aid was provided. Such governmental control over international transactions limited the risk of misappropriating funds.

Comparatively, the sub-Saharan African context offers a different picture of the use of official development assistance. As we have stated above, part of the explanation is the absence of strong institutional structures capable of protecting property rights, ensuring political stability, and directing and guiding the citizens and investors through transparent and accountable government toward economic growth with an improved standard of living similar to South Korea. Because the issue of governance is central to our argument, it is important to note our characterization/definition of the concept. As Kalu has argued, governance is characterized by acceptable norms, institutions, and cultures of people, framed around a common language in a territorially delineated space. Structurally, it deals with the specific functions and responsibilities of different machineries of government or institution within a given society or state (Kalu 2005: 174). Contemporary global governance is characterized by a system of multi-layered authority and policy making in such contexts as the United Nations, the European Union, states, communities and individual units ${ }^{12}$ such as families. The issue of governance has become so important that by the 1990s, even the World Bank became cognizant of the fact that the economy requires political dimension for its growth. Subsequently, effective and accountable governance became part of the criteria for aid supported by the international financial institutions. Thus, for the World Bank, governance is "... the institutional capacity of public organizations to provide the public and other goods demanded by a country's citizens or their representatives in an effective, transparent, impartial, and accountable manner" (The World Bank 2000, 48). And with the new realization, sub-Saharan African states were yet again expected to make significant gains in economic growth based on official development assistance within the framework of good 
governance. And, yet again, as the case of sub-Saharan Africa shows (see Figure 5), while foreign assistance declined a bit following the end of the cold war, it has been increasing with no subsequent improvement in the economic growth in the region.

Figure 5. COMbined Official. Aid and Development ASsistance for Sub-Saharan Africa and the Middie East/North Africa

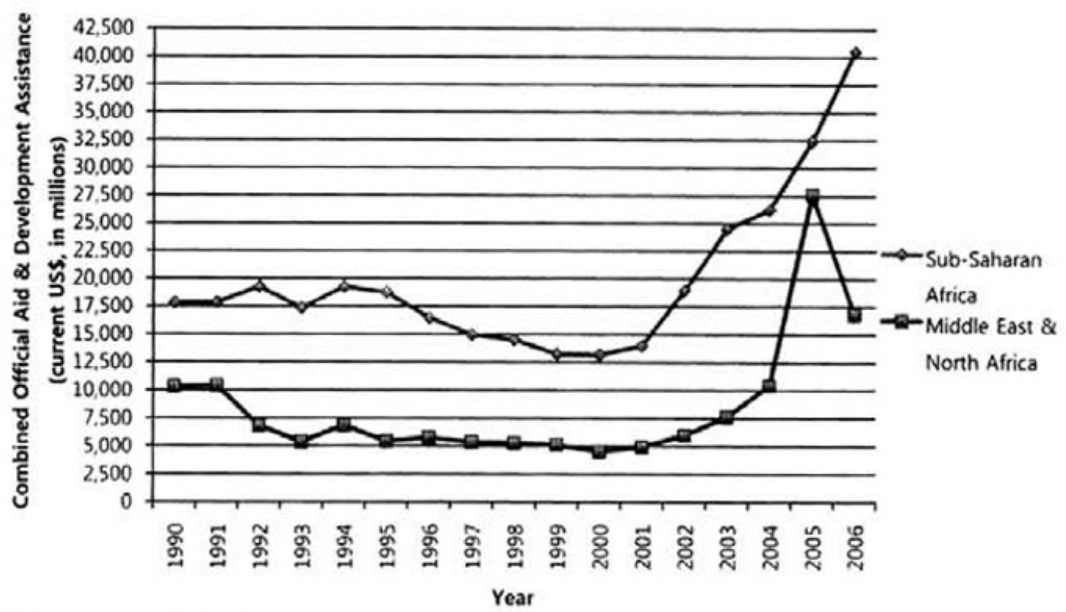

SOURCE: the world bank, 2008.

As Figure 5 shows, between 1990 and 2006, sub-Saharan Africa had generated more official development assistance than all of North Africa and the Middle East combined.13 Yet, World Bank data consistently show North African and Middle Eastern states fare better in terms of its political stability, having an economic growth rate of $4.2 \%$ between 2000 and 2006, advanced infrastructure, and having over $90 \%$ of their children complete primary education. Unarguably, strong political institutions, which North African and Middle Eastern countries are famous for, in addition to their luck of geography, i.e. oil rich, are significant factors explaining their improved standard of living, effective use of official development assistance and increasing level of economic growth compared to sub-Saharan African states whose economies and standard of living continue to decline. This is evident in the 1999 UNDP Human Development Index (HDI), which showed that 29 of the 35 countries in the "low human development" category are African states. ${ }^{14}$ For its 2007/2008 HDR report, UNDP 2005 data shows that all the 21 countries classified under the category of "low human development" are sub-Saharan African states, and most states at the bottom half of the "medium human development" category are still African states, which overall, is not a significant improvement from 1999 to 2005.15 In 2007, aggregate data show sub-Saharan Africa's total external debt at $34.2 \%$ of its Gross Domestic Product. 
And with increasing population, most of whom fall in the dependent category, a gross national income (GNI) per capita of $\$ 751$ (The World Bank 2008: 10) hides the gross disparities in the region. For example, while South Africa and Nigeria make up $54 \%$ of sub-Saharan Africa's total GNI; between the two, only $10.7 \%$ of the South African population lives on less than $\$ 1$ per day whereas in Nigeria, $70.8 \%$ of the population lives on less than $\$ 1$ per day. ${ }^{16}$ Indeed, if $\$ 2$ per day is used as a measure of poverty level in East, Central, and West Africa, "the percentage of the population living on less than US\$2 per day was one-half or greater in every country except Cote d'Ivoire (where it was 49 percent), and 90 percent or higher in Nigeria and Tanzania."17While aggregate GDP for sub-Saharan Africa is approximately $\$ 630$ billion, central government revenue is $25 \%$ of the total. While foreign direct investment in the region was a little over $\$ 20$ billion for 2007 , sub-Saharan Africa citizens working outside of their country remitted a total of $\$ 2.4$ billion back to the region in 2007 (The World Bank 2008). Also, for the region, net aid for 2007 was $\$ 31$ billion which is approximately $5 \%$ of the GDP, and constitutes $28 \%$ of central government expenditure in 2007. This is empirical evidence that something is fundamentally wrong in much of sub-Saharan Africa. It is the lack of visionary leadership, strong political and economic institutions, transparent and accountable governance, and a culture of patriotism that hinders development and the effective use of official development assistance to improve the standard of living of their citizens.

But, the difficult question is: Can we apply the South Korean model to sub-Saharan Africa? As we have argued, the root cause of underdevelopment and ineffective infrastructure in many sub-Saharan states goes back to the colonial period, and certainly, it is not an easy task to establish a strong, efficient state with clear vision and will for development. It is a long-term project, but one that requires commitred and visionary leadership. Development, especially in contemporary global economic systems, clearly shows that external and domestic factors have to work in tandem without violating international rule of state sovereignty or international norms, to achieve economic growth. Still, we think that the international donors and financial experts should focus on communicating with recipients in ways that guide them towards good governance -- development of strong political and economic institutions that utilize aid and domestic savings for development purposes. This study shows that good governance, rather than abundance of foreign aid, is the determining factor for producing the developmental state. More honest and transparent involvement by the donor countries in the process of distribution and usage of the aid could help enhance the effectiveness and use of foreign aid for the intended purpose in African states. Countries like South Korea which succeeded in transforming its industrial structure could provide specific know-how and share its experience with sub-Saharan nations. Lastly, we believe that by demonstrating the importance of the role of the state and showing that it actually works, the South Korean experience could 
contribute to the establishment of good governance in sub-Saharan Africa through inter-institutional and inter-state scientific and educational collaborations as well as joint-ventures in research and manufacturing activities.

\section{REFERENCES}

Ake, Claude. 1996. Democracy and Development in Africa, Washington, D.C.: The Brookings Institution.

Amsden, Alice. 1989. Asia's Next Giant: South Korea and Late Industrialization, New York: Oxford University Press.

Brownlie, Ian. 1979. Principles of Public International Law, 3rd ed. Oxford: Clarendon Press.

Easterly, William. 2006. The White Man's Burden: Why the West's Efforts to Aid the Rest Have Done So Mucb IIl and So Little Good. New York: Penguin Books.

Evans, Peter. 1995. Embedded Autonomy: States and Industrial Transformation. New Jersey: Princeton University Press.

Ferguson, Yale H. and Richard W. Mansbach. 1989. The State, Conceptual Chaos, and the Future of International Relations Theory. Boulder and London: Lynne Rienner Publishers.

Gordon, Scott. 1999. Controlling the State: Constitutionalism from Ancient Athens to Today. Cambridge, Massachusetts: Harvard University Press.

Geertz, Clifford. 1981. Negara: The Theatre State in Nineteenth Century Bali. Princeton, New Jersey: Princeton University Press.

Halliday, Fred. 2001. The World At 2000. New York: Palgrave, 2001.

Herbst, Jeffrey. 2000. States and Power in Africa: Comparative Lessons in Authority and Control. New Jersey: Princeton University Press.

Kalu, Kelechi. 2005. Global Liberalism and Indigenous Governance in Africa in Globalization and Marginalization: Essays on The Paradoxes of Global and Local Forces, eds. Olufemi Vaughan, Marcheta Wright and Charles Small. Ibadan, Nigeria: Sefer Press.

Kalu, Kelechi. 2001. Political Economy of State Reconstitution in Africa in Contending Issues in African Development: Advances, Challenges, and the Future, eds. Obioma Iheduru. Westport, Connecticut: Greenwood Press.

Kim, E. M. 1992. Strong State, Big Business. SUNY Press.

Kim, J. 1988. The US Foreign Aid to South Korea during the 1950s and the South Korean Finance (in Korean). Economy and Society 1.

Kohli, Atul. ed. 1986. The State and Development in the Third World. Princeton, New Jersey.

KOICA. 2004. Development Assistance and Cooperation to South Korea (in Korean). Seoul: KOICA.

Krasner, Stephen D. 1984. Approaches to the State: Alternative Conceptions 
and Historical Dynamics. Comparative Politics 16(2): 223-246.

Krasner, Stephen D. 1978. Defending the National Interest: Raw Materials Imvestments and U.S. Foreign Policy. Princeton, New Jersey: Princeton University Press. Laski, H. J. 1935. The State as a Concept in Theory and Practice. London: The Viking Press.

Lenin, V. I. 1932. State and Revolution. New York: International Publishers. Lentner, Howard H. 1984. "The Concept of the State: A Response to Stephen Krasner," Comparative Politics 16(3): 367-377.

Lubasz, Heinz. 1974. The Developoment of the Modern State. New York: Macmillan. Ministry of Finance; Korea Industrial Bank. 1993. Foreign Income to South Korea, 1950s-1980s (in Korean). Seoul: Ministry of Finance; Korea Industrial Bank.

Nordlinger, Eric. 1981. On the Autonomy of the Democratic State. Cambridge: Harvard University Press.

Grew, Raymond. ed. 197. Crises of Political Development in Europe and the United States. Princeton, New Jersey: Princeton University Press.

Sachs, Jeffrey D. 2005. The End of Poverty: Economic Possibilities for Our Time. New York: Penguin Books.

Skowronek, Stephan. 1982. Building a New American State: The Expansion of National Administrative Capacities. New York: Cambridge University Press.

Tilly, Charles. 1985. War Making and State Making as Organized Crime in Bringing the State Back In, eds. Peter B. Evans, Dietrich Rueschemeyer, and Theda Skocpol. New York: Cambridge University Press.

Tilly, Charles. ed. 1975. The Formation of National States in Western Europe. Princeton, New Jersey: Princeton University Press.

Trimberger, Ellen Kay. 1978. Revolution from Above: Military Bureaucratics and Development in Japan, Turkey, Egypt, and Peru. New Brunswick: Transaction Books. UNDP. 2008. Human Development Report 2007/2008. New York: Oxford University Press.

UNDP. 1999. Human Development Report 1999. New York: Oxford University Press.

Vogel, Ezra F. 1991. The Four Little Dragons: The Spread of Industrialization in East Asia, Cambridge; London: Harvard University Press.

Watkins, Frederick M. 1934. The State as a Concept in Political Science. New York: Harper and Brothers Publishers.

Weber, Max. 1964. The Theory of Social and Economic Organization. ed. Talcot Parsons New York: Free Press.

The World Bank. 2008. The Little data Book on Africa 2007. Washington, D.C.: The World Bank.

The World Bank. 2000. Can Africa claim the 21" Century. Washington, D.C.:

The World Bank. 


\section{ENDNOTES}

'See Ferguson and Mansbach (1989: 18).

2 For specific debares and definitions of the state the following works should be helpful. Weber (1964), Trimberger (1978), Brownlie (1979), Nordlinger (1981), Geertz (1981), Skowronek (1982), Tilly, ed. (1975), Grew, ed. (1978), Laski (1935), Watkins (1934), Lubasz (1974). Also, see Krasner (1984), Lentner (1984), Kohli, ed. (1986), and, Lenin (1932).

3 Howard Lentner, op. Cit., p. 368.

See Herbst (2000), especially chapters 5-6.

Cited in Gordon, 1999: 11.

"For empirical definitions and data for different countries, see World Bank Governance Indicators (1996 2007) hete://info.worldbank.org/governance/wgi/index.asp 2009.

Korea International Cooperation Agency (KOICA) database.

${ }^{8}$ South Korea's fiscal year begins in January and ends in December. Rhee adopted the American fiscal year system only temporarily to maximize the efficacy of the US foreign assistance to South Korea.

'Because of the 'Buy American Policy,' South Korean government was pressured to purchase the American products for the aid goods and use American ships in transporting them (Ministry of Finance; Korea Industrial Bank 1993: 63).

${ }^{10}$ President Rhee stepped down in 1949 pressured by student movements. Jang regime was established through a democratic election and adopted a parliamentary system.

"For more about South Korea's rapid economic growth, see Vogel (1991), Amsden (1989) and; E. M. Kim (1992), among many.

12 See, Halliday (2001: 133).

${ }^{13}$ Contrary to the comment by one of the reviewers for this paper, the intent in presenting this figure is to show how a region that includes countries in Africa but enjoys measurable level of political stability as table 1 shows, is also as indicated here able to generate official development assistance to the benefit of their citizens. Ignoring the Middle East/North Africa data does not in any substantive way undermine the analytical depth the data show.

14 The data analysis in this section relies on Kelechi Kalu, "Strong Institutions \& Foreign Direct Investment: Agenda for Sensible Development in Africa,"a keynote address delivered at the International Conference on Emerging Donors and New Approaches to Development Cooperation" at Ewha Womans University, Seoul, South Korea, (December 4-5, 2008): 24-25.

15 UNDP(1999: 57); UNDP(2008: 229-232).

${ }^{16}$ Sce World Bank Africa Development Indicators at hrtp://web.worldbank.org/Website/external/countries/ Africaext/extpub retrieved November 24, 2008.

"See "Africa Population Data Sheet" (2008): 4 retrieved from Population Research Bureau website at http://www.prb.org and African Population and Health Research Center data online at http://www.aphrc.org. 